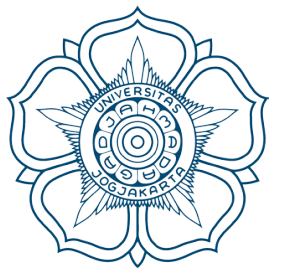

Judul Naskah

: ASPEK HUKUM PERAN SERTA MASYARAKAT DALAM PELESTARIAN CAGAR BUDAYA

Nama Penulis : Fajar Winarni

MIMBAR HUKUM

$\begin{array}{ll}\text { DOI } & : \text { http://doi.org/10.22146/jmh.29160 } \\ \text { Penerbit } & : \text { Fakultas Hukum Universitas Gadjah Mada } \\ \text { URL } & : \text { jurnal.ugm.ac.id/jmh } \\ \text { E Issn } & : 2443-0994 \\ \text { P Issn } & : 0852-100 x\end{array}$




\title{
ASPEK HUKUM PERAN SERTA MASYARAKAT DALAM PELESTARIAN CAGAR BUDAYA*
}

\author{
Fajar Winarni*** \\ Departemen Hukum Lingkungan \\ Fakultas Hukum Universitas Gadjah Mada, Yogyakarta \\ Jalan Sosio Yustisia No. 1, Bulaksumur Sleman, Yogyakarta 55281
}

\begin{abstract}
This research entitled "Aspek Hukum Peran Serta Masyarakat dalam Pelestarian Cagar Budaya” aims to examine the implementation of Cultural Heritage School and its setting in the future. This research is an empirical law study. Data analysis method used is descriptive qualitative. The results of this research are: First, the implementation of the activities is intended as an effort of socialization for the community, especially the younger generation, which is packed in the form of cultural heritage learning. Second, the setting of School of Cultural Heritage based on community participation and sustainable is to make it as a local content in the primary and secondary school curriculumand Governor Regulation.
\end{abstract}

Keywords: community, participation, school of cultural heritage, preservation.

\section{Intisari}

Penelitian dengan judul "Aspek Hukum Peran Serta Masyarakat Dalam Pelestarian Cagar Budaya" ini bertujuan untuk mengkaji pelaksanaan Sekolah Cagar Budaya dan pengaturannya mendatang. Penelitian ini merupakan penelitian hukum empiris. Metode analisis data yang digunakan adalah deskriptif kualitatif. Hasil penelitian adalah: Pertama, pelaksanaan kegiatan dimaksudkan sebagai upaya sosialisasi bagi masyarakat terutama generasi muda, yang dikemas dalam bentuk pembelajaran cagar budaya. Kedua, pengaturan Sekolah Cagar Budaya berbasis partisipasi masyarakat dan berkelanjutan adalah menjadikannya sebagai muatan lokal dalam kurikulum sekolah dasar dan menengah, serta dituangkan dalam bentuk Peraturan Gubernur.

Kata Kunci: peran serta, masyarakat, sekolah cagar budaya, pelestarian.

\section{Pokok Muatan}

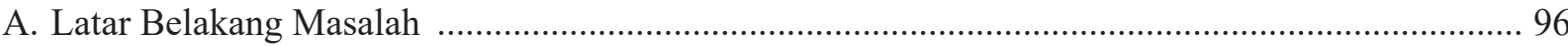

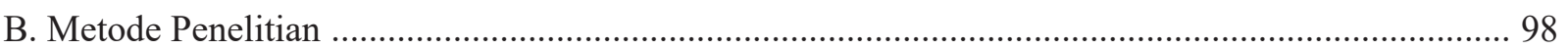

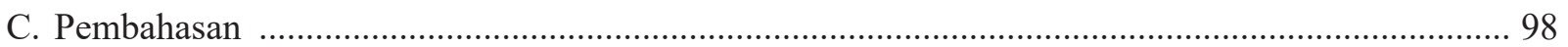

1. Pelaksanaan Sekolah Cagar Budaya oleh BPCB Provinsi DIY Sebagai Bentuk Peran Serta

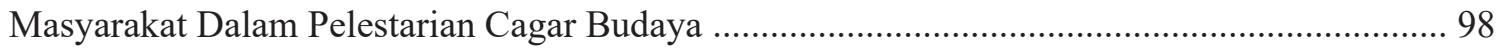

2. Pengaturan Sekolah Cagar Budaya Berbasis Partisipasi Masyarakat dan Berkelanjutan ........... 101

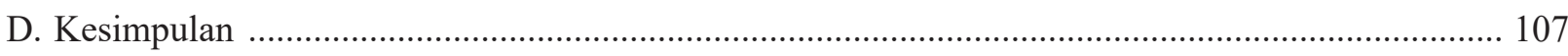

Penelitian didanai Unit Riset dan Publikasi FH UGM Tahun 2017.

** Alamat Korespondensi: fajar.winarni@mail.ugm.ac.id. 


\section{A. Latar Belakang Masalah}

Berdasarkan Pasal 32 ayat (1) UUD NRI

Tahun 1945, Negara Indonesia memajukan kebudayaan Indonesia di tengah-tengah peradaban dunia dengan memberikan kebebasan masyarakat untuk memelihara dan mengembangkan nilainilai budayanya. Nilai-nilai luhur budaya Bangsa Indonesia menjadi penting untuk dipertahankan keberadaannya karena dapat memperkuat jati diri, harkat dan martabat, serta ikatan rasa kesatuan dan persatuan bangsa. Oleh karena itu, dalam rangka mempertahankan itu semua diperlukan peran serta masyarakat.

Peran serta masyarakat tersebut merupakan salah satu asas dalam pelestarian cagar budaya. Artinya, setiap anggota masyarakat didorong untuk berperan aktif dalam pelestarian cagar budaya. Adapun yang dimaksud dengan pelestarian cagar budaya menurut Pasal 1 angka 22 UndangUndang No. 11 Tahun 2010 tentang Cagar Budaya (UUCB) adalah upaya dinamis untuk mempertahankan keberadaan cagar budaya dan nilainya dengan cara melindungi, mengembangkan, dan memanfaatkannya. Keberadaan cagar budaya beserta nilai-nilai yang terkandung di dalamnya juga penting untuk dipertahankan karena cagar budaya merupakan salah satu aset wisata yang besar.

Kesadaran untuk melestarikan cagar budaya telah tumbuh sejak tahun 1972 dengan dibentuknya Convention concerning the Protection of the World Cultural and Natural Heritage atau disingkat sebagai WHC (World Heritage Convention). Timbulnya gagasan untuk membentuk konvensi tersebut didasarkan pada kenyataan bahwa waktu telah membawa kemusnahan bagi kreasi manusia dan alam. Tindakan destruktif yang ditimbulkan oleh manusia dan alam telah mengancam, merusak, atau memusnahkan banyak properti yang mempunyai makna universal. ${ }^{1}$

Obyek wisata budaya mempunyai daya tarik tinggi karena memiliki nilai khusus dalam bentuk atraksi kesenian, upacara-upacara adat, nilai luhur yang terkandung dalam suatu obyek buah karya manusia pada masa lampau. ${ }^{2}$ Keberadaan cagar budaya berfungsi untuk menarik para wisatawan baik wisatawan nusantara maupun mancanegara untuk berkunjung ke Yogyakarta. Namun demikian, perusakan cagar budaya oleh orang-orang yang tidak bertanggung jawab masih sering terjadi.

Bersamaan dengan perkembangan kota menjadi kota yang modern, terjadi banyak pembongkaran benda-benda bersejarah menjadi bangunan modern. Apabila hal ini dibiarkan jelas akan menimbulkan ancaman terhadap kelestarian cagar budaya. Bahkan dikhawatirkan dalam jangka panjang sedikit demi sedikit cagar budaya tersebut akan punah dan cerita bersejarah yang melekat pada cagar budaya juga akan hilang. Oleh karena itu perlu ada perhatian yang serius terhadap cagar budaya dengan memberikan perlindungan yang lebih kuat untuk menjaga dan menjamin kelestariannya. ${ }^{3}$

Upaya pelestarian tersebut membutuhkan keikutsertaan masyarakat. Undang-Undang No. 32 Tahun 2009 tentang Perlindungan dan Pengelolaan Lingkungan Hidup (UUPPLH) mengatur bahwa peran serta masyarakat merupakan hak. Pasal 65 ayat (4) UU a quo menyatakan bahwa setiap orang berhak untuk berperan dalam perlindungan dan pengelolaan lingkungan hidup sesuai dengan peraturan perundang-undangan. Pengelolaan lingkungan hidup termasuk di dalamnya adalah pelestarian cagar budaya, karena cagar budaya merupakan salah satu komponen lingkungan hidup. Komponen lingkungan hidup mencakup komponen biotik atau hayati, komponen abiotik atau fisik, dan komponen sosial budaya yaitu manusia dan

Koesnadi Hardjasoemantri, "Kajian Hukum dan Peraturan Perundang-undangan dalam Pelestarian Warisan Budaya Candi Prambanan", dalam Himawan Pambudi, 2006, Ekologi, Manusia, dan Kebudayaan (Kumpulan Tulisan Terpilih Prof. Dr. Koesnadi Hardjasoemantri, S.H., M.L.), Lapera Pustaka Utama, Yogyakarta, hlm. 252-253.

Putu Tuni Cakabawa, "Potensi Kearifan Lokal Dalam Pembangunan Berwawasan Lingkungan", dalam Laode M. Syarif dan Andri G. Wibisana, tanpa tahun, Hukum Lingkungan: Teori, Legislasi, dan Studi Kasus, USAID, Jakarta, hlm. 700.

Francisca Romana Harjiyatni dan Sunarya Raharja, "Perlindungan Hukum Benda Cagar Budaya Terhadap Ancaman Kerusakan di Yogyakarta", Mimbar Hukum, Vol. 24, No. 2, Juni 2012, hlm. 346-347. 
perilakunya.

Pelibatan masyarakat sejak dini dalam masalah cagar budaya dari perencanaan sampai dengan pengambilan keputusan akhir, dapat memperkecil potensi timbulnya konflik cagar budaya. Masyarakat dilihat sebagai faktor yang dominan dalam pelestarian cagar budaya. Oleh karena peran serta masyarakat merupakan suatu hak, maka menjadi tanggung jawab Pemerintah untuk menjamin terpenuhinya hak tersebut, apalagi UUCB mempunyai orientasi pengelolaan cagar budaya yang bersifat partisipatif.

Pemerintah Pusat tidak mengambil peran sebagai penanggung jawab tunggal dalam sistem pengelolaan cagar budaya, tetapi melibatkan para stakeholder yang terdiri atas masyarakat, akademisi, Non Governmental Organization, pihak swasta, dan Pemerintah Daerah. Seiring dengan era reformasi yang bertumpu pada otonomi daerah maka peran Pemerintah Daerah baik tingkat provinsi maupun kabupaten atau kota mempunyai peran yang penting tidak hanya dalam perlindungan dan pengembangan, tetapi juga dalam pemanfaatan cagar budaya untuk kepentingan masyarakat. ${ }^{4}$

Salah satu contoh tanggung jawab Pemerintah adalah dicetuskannya kegiatan edukasi oleh Balai Pelestarian Cagar Budaya (BPCB) Provinsi Daerah Istimewa Yogyakarta. BPCB meluncurkan suatu program yang berbasis peran serta masyarakat dengan istilah Sekolah Cagar Budaya atau Sekolah Candi pada tahun 2017. Kegiatan ini merupakan salah satu upaya BPCB untuk memberikan pembelajaran bagi para generasi muda agar semakin paham sejarah, semakin bangga dan menghargai karya budaya negeri.

Sekolah Cagar Budaya dapat diikuti oleh kalangan mana pun. Program ini sebagai sarana pengenalan, pemahaman dan cara-cara penanganan terkait cagar budaya supaya masyarakat mengetahui cara memperlakukan cagar budaya.
Dengan demikian, hal tersebut akan menumbuhkan sikap suka rela dan kesadaran untuk melestarikan cagar budaya di DIY. Sebagai program baru yang dicanangkan oleh Balai Pelestarian Cagar Budaya (BPCB) Provinsi DIY, sosialisasi cagar budaya yang dikemas dalam bentuk pembelajaran cagar budaya di sekolah maupun di situs atau lokasi yang mengandung cagar budaya ini belum banyak diketahui oleh publik sehingga sangat penting untuk mengenalkan program ini kepada masyarakat terutama kepada generasi muda. ${ }^{5}$

Penanaman kesadaran mengenai pentingnya pelestarian cagar budaya sebagai salah satu identitas bangsa kepada generasi muda sangatlah tepat karena penerus bangsa ini yang harus menjaga dan mempertahankan keberadaan cagar budaya agar dapat dinikmati pula oleh generasi-generasi yang akan datang. Dengan demikian akan tercipta pelestarian cagar budaya yang berkelanjutan.

Selain itu, dengan sistem pendidikan seperti saat ini, nilai-nilai yang seharusnya menjadi bekal manusia Indonesia untuk menghadapi terjangan globalisasi dengan kearifan lokal, tidaklah dipunyai. Pendidikan melalui sekolah-sekolah lebih banyak memperkenalkan anak didik dengan kebudayaan barat daripada kebudayaan warisan nenek moyang. Perkenalan dengan kebudayaan warisan nenek moyang hanya terjadi secara kebetulan atas usaha pribadi atau kelompok kecil tertentu. Dengan demikian generasi muda tidak sempat menafsirkan dan mengkreasikan makna serta memanfaatkan kearifan lokal dalam pembangunan karakter bangsa. ${ }^{6}$ Upaya Pemerintah tersebut yang dalam hal ini adalah BPCB Provinsi DIY untuk mengadakan pembelajaran mengenai pentingnya pelestarian cagar budaya sejak dini perlu mendapat dukungan dari semua pihak agar generasi muda menghargai dan mencintai peninggalan atau warisan budaya bangsa.

Berdasarkan uraian pada latar belakang

Direktorat Pelestarian Cagar Budaya dan Museum, "Paradigma Pelestarian Cagar Budaya dan Permuseuman", http://kebudayaan.kemdikbud. go.id/ditpcbm/2015/05/11/paradigma-cagar-budaya-dan-permuseuman/, diakses 7 Mei 2017.

Cholis Faizi, "Ada Lagi Nih! Sekolah Cagar Budaya Agar Generasi Muda Mencintai Candi", http;//nasional.indopos.co.id/ read/2017/03/21/91982/Ada-Lagi-nih-Sekolah-Cagar-Budaya-Agar-Generasi-Muda-Mencintai-Candi, diakses 2 April 2017.

$6 \quad$ Ajip Rosidi, 2011, Kearifan Lokal Dalam Perspektif Budaya Sunda, Cetakan 1, Kiblat Buku Utama, Bandung, hlm. 43. 
masalah tersebut, maka rumusan masalah yang diangkat dalam tulisan ini adalah: Pertama, bagaimanakah pelaksanaan Sekolah Cagar Budaya oleh BPCB Provinsi DIY sebagai salah satu bentuk peran serta masyarakat dalam pelestarian cagar budaya? Kedua, bagaimanakah pengaturan Sekolah Cagar Budaya yang sebaiknya dikembangkan dalam tujuannya untuk menanamkan kepedulian masyarakat terhadap pelestarian cagar budaya?

\section{B. Metode Penelitian}

Penelitian ini merupakan penelitian hukum empiris, yang mengkaji pelaksanaan Sekolah Cagar Budaya oleh BPCB Provinsi DIY sebagai salah satu bentuk peran serta masyarakat dalam pelestarian cagar budaya, dan pengaturan Sekolah Cagar Budaya oleh BPCB Provinsi DIY di masa yang akan datang dalam tujuannya untuk menanamkan kepedulian masyarakat terhadap pelestarian cagar budaya. Bahan penelitian didapat dengan penelitian lapangan dan penelitian kepustakaan. Alat penelitian yang digunakan adalah wawancara dengan menggunakan pedoman wawancara, yaitu peneliti melakukan wawancara kepada narasumber dan responden secara terarah dengan menggunakan daftar pertanyaan sebagai pedoman. Narasumber dalam penelitian adalah Kepala BPCB Provinsi DIY, sedangkan responden dalam penelitian ini adalah pimpinan sekolah yang sudah pernah mengikuti program Sekolah Cagar Budaya, yaitu SD Kintelan 1 dan 2 Yogyakarta, SD Prawirataman Yogyakarta, SD Karanganyar Yogyakarta, dan SMP Negeri 2 Pleret Bantul. Metode analisis data yang digunakan adalah deskriptif kualitatif.

\section{Hasil Penelitian dan Pembahasan}

1. Pelaksanaan Sekolah Cagar Budaya oleh BPCB Provinsi DIY sebagai Bentuk Peran

Serta Masyarakat dalam Pelestarian
Cagar Budaya

Sekolah Cagar Budaya merupakan salah satu program kegiatan yang diadakan oleh BPCB DIYdalam upaya meningkatkan internalisasi cagar budaya kepada masyarakat. Menurut Tri Yuliana, internalisasi cagar budaya maksudnya adalah suatu penghayatan atau penguasaan secara mendalam terhadap cagar budaya yang berlangsung melalui binaan atau bimbingan dari pihak BPCB DIY. Dalam proses internalisasi tersebut pola-pola budaya ditanamkan pada diri individu yang kemudian dibentuk menjadi sebuah kepribadian. Dengan kata lain internalisasi merupakan suatu proses penanaman nilai tentang budaya. Dalam penanaman dan penumbuhkembangan nilai tersebut dilakukan melalui berbagai pendidikan dan pengajaran, yang antara lain melalui Sekolah Cagar Budaya.?

Sekolah Cagar Budaya merupakan salah satu upaya untuk meningkatkan peran serta masyarakat terutama generasi muda dalam pelestarian cagar budaya. Pasal 2 huruf h UUCB menyatakan bahwa partisipasi atau peran serta adalah salah satu asas dalam pelestarian cagar budaya, yang berarti setiap anggota masyarakat didorong untuk berperan aktif dalam pelestarian cagar budaya. Sebagaimana diuraikan lebih lanjut dalam beberapa pasal UUCB, bahwa masyarakat dapat berperan serta dalam hal sebagai berikut:

a. $\quad$ Pasal 29 ayat (2): Setiap orang dapat berpartisipasi dalam melakukan pendaftaran terhadap benda, bangunan, struktur, dan lokasi yang diduga sebagai cagar budaya meskipun tidak memiliki atau menguasainya.

b. Pasal 56: Setiap orang dapat berperan serta melakukan perlindungan cagar budaya.

c. Pasal 63: Masyarakat dapat berperan serta melakukan pengamanan cagar budaya.

d. $\quad$ Pasal 78 ayat (2): Setiap orang dapat melakukan pengembangan cagar budaya setelah memperoleh izin Pemerintah atau Pemerintah Daerah dan pemilik dan/atau yang menguasai cagar budaya.

e. Pasal 99 ayat (2): Masyarakat ikut 
berperan serta dalam pengawasan pelestarian cagar budaya.

Dengan demikian berdasarkan UUCB, masyarakat dapat berperan serta dalam pendaftaran cagar budaya, perlindungan cagar budaya, pengamanan cagar budaya, pengembangan cagar budaya, dan pengawasan pelestarian cagar budaya, tanpa menyebutkan secara eksplisit bahwa peran serta itu sebagai suatu hak, mengingat dalam UUPPLH peran serta masyarakat diatur sebagai suatu hak.

Sementara itu, dalam Peraturan Pemerintah No. 10 Tahun 1993 tentang Pelaksanaan UndangUndang No. 5 Tahun 1992 tentang Benda Cagar Budaya Pasal 42 ayat (1) menyebutkan bahwa peran serta masyarakat dalam pelestarian atau pengelolaan benda cagar budaya dapat dilakukan oleh perorangan atau badan hukum, yayasan, perhimpunan, perkumpulan, atau badan lain yang sejenis. Berdasarkan ayat (2) pasal tersebut dinyatakan bahwa peran serta masyarakat dapat berupa penyuluhan, seminar, pengumpulan dana, dan kegiatan lain dalam upaya perlindungan dan pemeliharaan benda cagar budaya.

Terkait dengan Sekolah Cagar Budaya, adapun yang menjadi latar belakang BPCB DIY melaksanakan program ini, bahwa DIY memiliki potensi cagar budaya yang sangat besar, berupa benda cagar budaya, bangunan cagar budaya, struktur cagar budaya, situs cagar budaya, dan kawasan cagar budaya. Keanekaragaman cagar budaya tersebut berasal dari berbagai zaman, mulai dari masa pra sejarah, klasik (Hindu Budha), Islam, kolonial, dan kemerdekaan. Kekayaan warisan budaya DIY yang begitu besar perlu dilestarikan keberadaannya, mengingat di dalamnya terkandung nilai penting bagi sejarah, ilmu pengetahuan, pendidikan, agama, dan kebudayaan. ${ }^{8}$

Sekolah Cagar Budaya dilaksanakan atas dasar hukum sebagai berikut:

a. Undang-Undang No. 11 Tahun 2010 tentang Cagar Budaya; b. Keputusan Menteri Pendidikan dan Kebudayaan RI No. 9237/A4.4/ KP/2012;

c. Peraturan Menteri Pendidikan dan Kebudayaan RI No. 52 Tahun 2012 tentang Organisasi dan Tata Kerja Balai Pelestarian Cagar Budaya;

d. Peraturan Menteri Pendidikan dan Kebudayaan RI No. 28 Tahun 2013 tentang Rincian Tugas Balai Pelestarian Cagar Budaya;

e. DIPA Balai Pelestarian Cagar Budaya Daerah Istimewa Yogyakarta tahun anggaran 2017: SP DIPA No. 023.15.2.427798/2017 tanggal 7 Desember 2016;

f. Petunjuk Operasional Kegiatan balai pelestarian Cagar Budaya Tahun 2017;

g. Program Kerja Balai Pelestarian Cagar Budaya Daerah Istimewa Yogyakarta Tahun anggaran 2017.

Upaya pelestarian cagar budaya yang dilakukan oleh BPCB DIY bersifat menyeluruh. Pelestarian cagar budaya tidak hanya fokus pada aspek kuantitatif, namun juga mencakup aspek kognitif, afektif, dan psikomotorik. Selain melakukan pelestarian yang bersifat fisik melalui kegiatan pemeliharaan dan pemugaran cagar budaya, BPCB DIY juga melaksanakan internalisasi cagar budaya kepada masyarakat termasuk kepada pelajar. Kegiatan Sekolah Cagar Budaya merupakan sosialisasi bagi pelajar yang dikemas dalam bentuk pembelajaran cagar budaya di sekolah maupun di situs atau lokasi yyang mengandung cagar budaya.

Berdasarkan hasil wawancara, BPCB DIY menilai bahwa kegiatan ini sangat penting, karena masih banyak pelajar yang belum mengetahui potensi cagar budaya yang ada di DIY dan memahami nilai-nilai penting yang terkandung didalamnya. Sebagaimana yang diamanatkan dalam UUCB, pelestarian cagar budaya dilakukan dengan berasaskan partisipasi yakni melibatkan masyarakat khususnya pelajar. Sekolah Cagar Budaya pendidikan karakter bangsa ini dilaksanakan dengan tema "membangun generasi peduli budaya, 
berkarakter, dan berintegritas". Kesadaran dan kepedulian akan arti penting pelestarian cagar budaya harus dilaksanakan sejak dini dan secara berkelanjutan. ${ }^{9}$

Kegiatan Sekolah Cagar Budaya bermaksud untuk melakukan pembelajaran, baik pengenalan maupun memberikan pemahaman mengenai cagar budaya kepada pelajar atau peserta didik. Tujuan Sekolah Cagar Budaya adalah sebagai berikut: ${ }^{10}$

a. Pelajar dapat mengetahui perkembangan kondisi cagar budaya yang ada di DIY;

b. Meningkatkan wawasan pelajar tentang cagar budaya dan menumbuhkan apresiasi pelajar terhadap eksistensi cagar budaya;

c. Mensosialisasikan peraturan perundang-undangan cagar budaya, dan berbagai kegiatan pelestarian cagar budaya dari berbagai aspek;

d. Mengenalkan potensi cagar budaya yang ada di DIY dalam rangka memupuk rasa kebanggaan nasional dan mempertebal jati diri bangsa;

e. Membangun pemahaman pelajar tentang arti penting karyya peradaban bangsa;

f. Membangun karakter pelajar yang selaras dengan kebudayaan bangsa Indonesia.

Kegiatan Sekolah Cagar Budaya diselenggarakan di dua tempat, yaitu: ${ }^{11}$

a. Sekolah, yang didatangi oleh Tim BPCB DIY dan menjadi tempat kegiatan. Pada kegiatan ini diadakan pemutaran film tentang cagar budaya dan penyuluhan peraturan perundangundangan cagar budaya. Kegiatan ini dapat dilakukan di sekolah atau di situs terdekat yang ditentukan. Peralatan, konsumsi, dan pelaksanaan kegiatan disediakan dan dilakukan oleh BPCB DIY. Peserta tidak dipungut biaya apa pun, seluruh biaya berasal dari APBN.

b. Situs atau di lokasi yang mengandung cagar budaya, dengan mengajak pelajar ke situs atau lokasi yang sudah ditentukan oleh tim Sekolah Cagar Budaya BPCB DIY. Peralatan, konsumsi, transportasi, dan pelaksanaan kegiatan disediakan dan dilakukan oleh BPCB DIY.

Persentase perbandingan dalam penyelenggaraan di dua tempat tersebut adalah $30 \%$ indoor (di sekolah) dan $70 \%$ outdoor (di situs). Adapun materi yang diberikan adalah sebagai berikut: ${ }^{12}$

a. Cagar budaya dan aspek-aspek yang melingkupinya;

b. Peraturan perundang-undangan cagar budaya;

c. Keterampilan yang berdaya guna bagi pelajar untuk berpartisipasi dalam pelestarian cagar budaya, antara lain pengenalan ekskavasi, identifikasi, preservasi konservasi, deskripsi, publikasi, pemanduan, dan fotografi cagar budaya.

Waktu pelaksanaan kegiatan Sekolah Cagar Budaya ini kurang lebih 5 jam atau menyesuaikan. Pelaksanaan kegiatan meliputi: pembukaan, pemberian materi cagar budaya beserta aspekaspeknya, penutup. Kegiatan per paket sebanyak 50 peserta termasuk pendamping. Pemohon dapat mengajukan dua paket kegiatan atau 100 peserta.

Kepala BPCB DIY mengeluarkan penetapan standar pelayanan Sekolah Cagar Budaya, dengan Surat Keputusan Kepala BPCB DIY No. 665/E.18/ IQ/2017 tentang Penetapan Standar Pelayanan Sekolah Cagar Budaya di Balai Pelestarian Cagar Budaya Daerah Istimewa Yogyakarta sebagai dasar operasional kegiatan Sekolah Cagar Budaya. Berdasarkan surat keputusan tersebut masyarakat yang akan mengikuti program atau kegiatan Sekolah Cagar Budaya harus mengajukan surat permohonan ke BPCB DIY, dapat secara online, manual maupun datang langsung ke kantor BPCB DIY.

Balai Pelestrian Cagar Budaya, 2017, Brosur Sekolah Cagar Budaya Pendidikan Karakter Bangsa, Pelestarian Cagar Budaya, Yogyakarta. Hasil wawancara dengan BPCB DIY (Bpk. Ign. Eka Hadiyanta) pada hari Kamis 22 Juni 2017.

Ibid. 
Kegiatan Sekolah Cagar Budaya diadakan terkait dengan tugas dan wewenang Pemerintah Daerah dalam pelestarian cagar budaya yang diatur dalam UUCB Pasal 95 dan Pasal 96. Berhubung Sekolah Cagar Budaya merupakan program BPCB yang baru diluncurkan pada tahun 2017, maka saat awal peluncurannya tentu belum banyak masyarakat yang mengetahuinya, sehingga salah satu cara yang dilakukan BPCB DIY untuk mensosialisasikan programnya adalah dengan mengirimkan surat pemberitahuan ke sekolah-sekolah. Cara ini mendapatkan sambutan yang antusias dari sekolah-sekolah, dengan banyaknya sekolah yang mengajukan permohonan untuk mengikuti Sekolah Cagar Budaya.

Dari hasil wawancara yang penulis lakukan dengan beberapa sekolah (SD Negeri 1 Kintelan, SD Negeri 2 Kintelan, SD Karanganyar, SD Prawirotaman, dan SMP Negeri 2 Pleret), semuanya menyambut baik program ini, karena bermanfaat bagi peserta didiknya. Namun pihak sekolah berharap untuk waktu yang akan datang, BPCB DIY lebih banyak melakukan sosialisasi berupa penyuluhan terkait Sekolah Cagar Budaya di sekolah-sekolah, baik penyuluhan kepada guru dan siswa maupun kepada orang tua siswa, karena selama ini BPCB DIY belum pernah melakukan penyuluhan itu ke sekolah-sekolah. Selain itu, juga perlu ada penambahan tim edukasi di lapangan atau di lokasi cagar budaya pada saat pelaksanaan kegiatan Sekolah Cagar Budaya. ${ }^{13}$

Sosialisasi yang dilakukan oleh BPCB DIY adalah membuat leaflet, membuat silabus, sosialisasi melalui media sosial dan elektronik, dan mengirim email ke instansi, sedangkan untuk sosialisasi dengan mendatangi sekolah-sekolah memang belum dilakukan. Prospek Sekolah Cagar Budaya ini adalah membangun pemahaman komprehensif tentang cagar budaya, sehingga akan muncul kesadaran dari masyarakat luas untuk melestarikan cagar budaya di daerahnya.

\section{Pengaturan Sekolah Cagar Budaya Berbasis Partisipasi Masyarakat dan Berkelanjutan.}

Sekolah Cagar Budaya merupakan suatu kegiatan yang patut mendapatkan dukungan dari seluruh lapisan masyarakat. Melalui kegiatan ini masyarakat khususnya generasi muda akan semakin mencintai dan menghargai budaya negeri sendiri.

Fenomena yang terjadi adalah masyarakat Indonesia merasa rendah diri terhadap kebudayaannya sendiri yang muncul dari hubungan antara kebudayaan barat dengan kebudayaan daerah di Indonesia. Rendah diri ini disebabkan oleh penjajahan, kerusakan perilaku masyarakat Indonesia, dan pencitraan yang kuat dari media tentang keunggulan kebudayaan barat. Saat ini mulai disadari bahwa kebudayaan daerah di Indonesia mempunyai keunggulan, mulai dari pandangan tentang alam hingga pranata sosial. ${ }^{14}$ Sudah saatnya masyarakat berupaya menjaga, merawat, melindungi, dan mempublikasikan kekayaan cagar budaya Indonesia kepada dunia untuk mengukuhkan identitas Indonesia sebagai bangsa yang bermartabat sebab hanya dengan memahami dan menjaga kekayaan cagar budaya dan sejarah, bangsa ini akan dihargai dan dipandang secara terhormat oleh bangsa lain. ${ }^{15}$

Sebagai salah satu upaya melestarikan cagar budaya DIY, Sekolah Cagar Budaya diharapkan dapat meningkatkan kesadaran masyarakat khususnya generasi muda untuk berperan serta dalam menjaga dan mempromosikan cagar budaya DIY, sehingga akan lebih menarik para wisatawan. Terlebih dalam kegiatan Sekolah Cagar Budaya juga disosialisasikan peraturan perundangundangan terkait cagar budaya, sehingga diharapkan kesadaran hukum masyarakat semakin meningkat dalam melestarikan cagar budaya di DIY.

Alam dan budaya merupakan komoditi dari usaha pariwisata. Objek dan daya tarik wisata adalah suatu bentukan atau aktivitas dan fasilitas yang

13 Hasil wawancara dengan Kepala Sekolah SDN 1 Kintelan, SDN 2 Kintelan, SD Karanganyar, SD Prawirotaman, SMP N 2 Pleret, pada hari Senin 5 Juni 2017.

14 Rusmin Tumanggor, Kholis Ridho, Nurochim, 2015, Ilmu Sosial dan Budaya Dasar, Edisi ke 3, Cetakan ke 4, Prenadamedia Group, Jakarta, hlm. 47-48. 
dapat menarik minat wisatawan atau pengunjung untuk datang ke suatu tempat atau daerah tertentu. Menurut Happy Manurung sebagaimana dikutip oleh Putu Tuni Cakabawa, menyebutkan bahwa secara garis besar objek dan daya tarik wisata diklasifikasikan ke dalam 3 (tiga) hal yaitu, daya tarik wisata alam, daya tarik wisata budaya, dan daya tarik buatan manusia. Ada juga yang membagi jenis objek dan daya tarik wisata ke dalam 2 (dua) kategori, yaitu objek dan daya tarik wisata alam, serta objek dan daya tarik wisata sosial budaya. ${ }^{16}$ Pasal 4 ayat (1) UU No. 9 Tahun 1990 tentang Kepariwisataan menyatakan bahwa objek dan daya tarik wisata terdiri atas: ${ }^{17}$

Objek dan daya tarik wisata ciptaan Tuhan Yang Maha Esa yang berwujud keadaan alam, serta flora dan fauna serta objek dan daya tarik wisata hasil karya manusia yang berwujud museum, peninggalan purbakala, peninggalan sejarah, seni budaya, wisata agro, wisata tirta, wisata buru, wisata petualangan alam, taman rekreasi, dan tempat hiburan.

Menurut Gamal Suwantoro sebagaimana dikutip oleh Putu Tuni Cakabawa, daya tarik suatu objek wisata didasarkan pada:

Adanya sumber daya yang dapat menimbulkan rasa senang, indah, nyaman, dan bersih; adanya aksesibilitas yang tinggi untuk dapat mengunjunginya; adanya ciri khusus atau spesifikasi yang bersifat langka; adanya sarana dan prasarana penunjang untuk melayani para wisatawan yang hadir; objek wisata alam mempunyai daya tarik tinggi karena keindahan alam pegunungan, sungai, pantai, pasir, hutan, dan sebagainya; objek wisata budaya mempunyai daya tarik tinggi karena memiliki nilai khusus dalam bentuk atraksi kesenian, upacara-upacara adat, nilai luhur yang terkandung dalam suatu objek buah karya manusia pada masa lampau.

Dengan demikian, objek dan daya tarik wisata harus dilindungi dilestarikan, dan dikembangkan, sehingga objek itu benar-benar dapat dimanfaatkan sebagai daya tarik wisata yang sesuai dengan keinginan pasar, namun tidak mengorbankan kepentingan budaya dan lingkungan hidup masyarakat setempat. ${ }^{18}$

Hukum merupakan pencerminan nilai-nilai yang terdapat di dalam masyarakat. Menanamkan kesadaran hukum berarti menanamkan nilainilai kebudayaan. Kesadaran hukum masyarakat merupakan pandangan-pandangan yang hidup dalam masyarakat tentang apa hukum itu. Pandangan yang hidup dalam masyarakat bukan semata-mata merupakan produk pertimbangan menurut akal, tetapi berkembang di bawah pengaruh beberapa faktor, seperti agama, ekonomi, politik, dan sebagainya. Sebagai pandangan hidup di dalam masyarakat, maka tidak bersifat perorangan atau subyektif, tetapi merupakan resultante dari kesadaran hukum yang bersifat subyektif. ${ }^{19}$

Menurut penulis, agar Sekolah Cagar Budaya lebih dikenal oleh masyarakat, perlu mengangkat Sekolah Cagar Budaya sebagai muatan lokal di sekolah-sekolah di Provinsi DIY di samping muatan lokal Bahasa Jawa yang selama ini telah berjalan, dengan dasar hukum Peraturan Gubernur DIY No. 64 Tahun 2013 tentang Mata Pelajaran Bahasa Jawa Sebagai Muatan Lokal Wajib di Sekolah/ Madrasah. Pasal 37 ayat (1) UU No. 20 Tahun 2003 tentang Sistem Pendidikan Nasional menyatakan bahwa kurikulum pendidikan dasar dan menengah wajib memuat Pendidikan Agama, Pendidikan Kewarganegaraan, Bahasa, Matematika, Ilmu Pengetahuan Alam, Ilmu Pengetahuan Sosial, Seni dan Budaya, Pendidikan Jasmani dan Olah Raga, Keterampilan dan Kejuruan, dan Muatan Lokal. Selanjutnya, dalam Penjelasan UU No. 20 Tahun 2003 disebutkan bahwa muatan lokal merupakan bahan kajian yang dimaksudkan untuk membentuk pemahaman peserta didik terhadap potensi di daerah tempat tinggalnya. Manfaat muatan lokal sebagaimana diatur dalam Lampiran II Peraturan

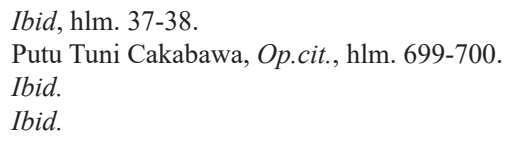


Menteri Pendidikan dan Kebudayaan RI No. 81A tahun 2013 tentang Implementasi Kurikulum adalah sebagai berikut: ${ }^{20}$

1. Mengenal dan menjadi lebih akrab dengan lingkungan alam, sosial, dan budayanya;

2. Memiliki bekal kemampuan dan keterampilan serta pengetahuan mengenai daerahnya yang berguna bagi dirinya maupun lingkungan masyarakat pada umumnya;

3. Memiliki sikap dan perilaku yang selaras dengan nilai-nilai atau aturanaturan yang berlaku di daerahnya, serta melestarikan dan mengembangkan nilai-nilai luhur budaya setempat dalam rangka menunjang pembangunan nasional.

Dengan demikian menurut Peraturan Menteri Pendidikan dan Kebudayaan No. 79 Tahun 2014 tentang Muatan Lokal Kurikulum 2013, muatan lokal diajarkan dengan tujuan membekali peserta didik dengan sikap, pengetahuan, dan keterampilan yang diperlukan untuk mengenal dan mencintai lingkungan alam, sosial, budaya, dan spiritual di daerahnya dan melestarikan keunggulan daerah yang berguna bagi diri dan lingkungannya dalam rangka menunjang pembangunan nasional. Oleh karena itu, menjadikan pengetahuan komprehensif tentang cagar budaya sebagai muatan lokal sesuai dengan kebutuhan masyarakat saat ini dan sesuai juga dengan manfaat dan tujuan muatan lokal yang telah disebutkan sebelumnya.

Adanya ide menambahkan kegiatan Sekolah CagarBudayamenjadimuatan lokaldalamkurikulum sekolah, memang sasarannya menjadi terbatas, yaitu hanya pelajar atau peserta didik tingkat dasar dan menengah, namun untuk masyarakat umum dapat dikemas dengan suatu kegiatan edukasi cagar budaya yang kegiatannya sama dengan program Sekolah Cagar Budaya saat ini. Dengan kata lain Sekolah Cagar Budaya ditujukan bagi masyarakat umum dengan pembelajaran dan materi yang sama dengan Sekolah Cagar Budaya yang dicantumkan sebagai muatan lokal di sekolah-sekolah. Terkait dengan hal ini, penulis membagi pokok pikiran ke dalam 3 hal, yaitu bentuk pengaturan Sekolah Cagar Budaya, materi yang akan diatur serta cakupan pengaturan Sekolah Cagar Budaya.

Usulan bentuk pengaturan adalah Peraturan Gubernur DIY. Pasal 31 ayat (1) UU No. 13 Tahun 2012 tentang Keistimewaan DIY, mengamanatkan kewenangan kebudayaan diselenggarakan untuk memelihara dan mengembangkan hasil cipta, rasa, karsa, dan karya yang berupa nilai-nilai pengetahuan, bahasa, norma, adat istiadat, benda, seni, dan tradisi luhur yang mengakar dalam masyarakat DIY. Selanjutnya, dalam pertimbangan pembentukan Peraturan Daerah Provinsi DIY No. 6 Tahun 2012 tentang Pelestarian Warisan Budaya dan Cagar Budaya, disebutkan bahwa DIY memiliki entitas atau tata pemerintahan berbasis kultural, sekaligus identitas lokal berupa nilai religi, nilai spiritual, nilai filosofis, nilai estetika, nilai perjuangan, nilai kesejarahan, dan nilai budaya yang menggambarkan segi keistimewaan Yogyakarta sehingga harus dijaga kelestariannya. Dari pertimbangan tersebut, penting untuk menanamkan pengertian pada masyarakat untuk melestarikan kebudayaan Yogyakarta yang tidak hanya berupa pelestarian nilai-nilai luhur yang diyakini oleh masyarakat, tetapi juga benda, bangunan, struktur, situs, dan kawasan cagar budaya. Dengan demikian akan ada 2 Peraturan Gubernur, yaitu Peraturan Gubernur tentang muatan lokal cagar budaya dan Peraturan Gubernur tentang Sekolah Cagar Budaya.

Adapun materi yang akan diatur dalam peraturan gubernur nantinya adalah mengenai cagar budaya dengan berbagai aspeknya, penegakan hukum di bidang cagar budaya, peraturan perundang-undangan terkait cagar budaya, contoh kasus-kasus di bidang cagar budaya baik mengenai gambaran perusakan atau kejahatan di bidang cagar budaya maupun upaya penegakan hukumnya, serta cagar budaya dipandang dari berbagai disiplin

19 Sudikno Mertokusumo, 2010, Bunga Rampai Ilmu Hukum, Cetakan ke 2, Liberty, Yogyakarta, hlm. 151.

20 Lampiran II Peraturan Menteri Pendidikan dan Kebudayaan RI No. 81A tahun 2013 tentang Implementasi Kurikulum. 
ilmu, misalnya ilmu hukum, ilmu arkeologi, ilmu sejarah, ilmu antropologi, ilmu lingkungan hidup, dan sebagainya. Sedangkan cakupoan pengaturan meliputi pemberian pemahaman mengenai cagar budaya bendawi dan cagar budaya non bendawi. Sebagaimana diketahui saat ini Yogyakarta menjadi salah satu kota tujuan wisata. Berbagai jenis objek wisata dikembangkan di wilayah ini, seperti wisata alam, wisata sejarah, wisata budaya, dan wisata pendidikan. Predikat sebagai kota pelajar berkaitan dengan sejarah dan peran kota ini dalam dunia pendidikan di Indonesia. Tidak berlebihan jika Yogyakarta disebut sebagai miniatur Indonesia. Kota Yogyakarta tampak terus dibenahi untuk menunjukkan jati dirinya sebagai pusat budaya, pusat pelajar, sekaligus pusat pariwisata.

Pemerintah Provinsi DIY terus membangun dan merevitalisasi berbagai fasilitas publik dan benda cagar budaya. Fasilitas publik seperti ruang terbuka hijau, taman pintar, perpustakaan kota, dan transportasi terus dibenahi. Fasilitas untuk para pecinta sepeda dilengkapi di berbagai ruas jalan, untuk memulihkan lagi budaya bersepeda. Demikian juga benda cagar budaya di lingkungan Keraton Yogyakarta Hadiningrat juga direvitalisasi. Berbagai kegiatan budaya terus digeliatkan untuk mengangkat citra Yogyakarta sebagai kota budaya. ${ }^{21}$

Kegiatan atau program Sekolah Cagar Budaya yang telah dicanangkan oleh BPCB DIY merupakan kegiatan yang berbasis pada partisipasi masyarakat. Upaya pelestarian cagar budaya di DIY memerlukan partisipasi masyarakat agar sebutan Yogyakarta sebagai kota budaya tetap dapat dipertahankan dan dijaga mengingat untuk saat ini banyak terjadi kerusakan bangunan cagar budaya di Yogyakarta. Kerusakan-kerusakan tersebut berupa goresan benda tajam, corat coret, noda, kotoran; cagar budaya tidak terpelihara dengan baik, misalnya rumah tinggal yang ditinggal pemiliknya, pemiliknya meninggal dunia, sedangkan ahli warisnya telah mempunyai rumah dan bertempat tinggal di kota lain; pemugaran oleh pemilik tanpa izin dari Pemerintah, sehingga mengubah bentuk yang mengakibatkan bentuk cagar budaya tidak sesuai lagi dengan aslinya. ${ }^{22}$

Fenomena pembongkaran bangunanbangunan warisan budaya, pembangunan yang mengabaikan eksistensi kawasan cagar budaya atau bersifat inkontekstual, dan kasus-kasus yang terkait dengan tindak pidana cagar budaya di DIY telah marak terjadi. Pembongkaran bangunan yang sudah masuk dalam daftar warisan budaya di kota Yogyakarta antara lain bangunan bekas Taman Ibu di Jl. Gajah Mada, bangunan Puskesmas Mergangsan di Jl. Kolonel Sugiono, dan penjualan rumah joglo di kawasan Kotagede. Pada tahun 2010 terjadi pencurian berbagai macam benda koleksi emas di museum negeri Sono Budoyo.

Terhadap kasus-kasus pelanggaran cagar budaya tidak dilakukan upaya represif, sehingga masyarakat mendapat kesan seolah-olah ada pembiaran terhadap berbagai kasus cagar budaya tersebut. Hal ini disebabkan oleh berbagai faktor, seperti masih terbatasnya cagar budaya yang mendapatkan legalitas formal di dalam proses penetapan, adanya persoalan teknis dalam proses penyelidikan dan penyidikan oleh PPNS cagar budaya, terutama yang terkait dengan aspek pelaksanaan manajemen penyidikan, juga sejauhmana kesiapan sumber daya manusia PPNS cagar budaya dalam mengawal penegakan hukum cagar budaya, serta sistem koordinasi pelaksanaan tugas dan fungsi PPNS cagar budaya yang belum dilakukan secara komprehensif dari pusat sampai daerah. ${ }^{23}$

Dari kenyataan-kenyataan seperti itulah langkah BPCB DIY mencanangkan program Sekolah Cagar Budaya perlu diapresiasi. Edukasi mengenai cagar budaya harus ditanamkan sejak dini kepada para generasi muda sebagai generasi penerus bangsa. Para peserta Sekolah Cagar Budaya diajak melakukan serangkaian kegiatan. Misalnya pelajar

\footnotetext{
21 Tasdiyanto Rohadi, 2011, Budaya Lingkungan: Akar Masalah dan Solusi Krisis Lingkungan, Cetakan ke 2, Ecologia Press, Yogyakarta, hlm. 44-45.

22 Francisca Romana Harjiyatni dan Sunarya Raharja, Op.cit., hlm. 349.
} 
SD Negeri 1 Kintelan, SD Negeri 2 Kintelan, SD Karanganyar, dan SD Prawirotaman diajak berkunjung ke situs cagar budaya Candi Sambisari Kelurahan Purwomartani, Kecamatan Kalasan DIY. Para pelajar dipandu berkeliling kompleks Candi Sambisari sambil dijelaskan mengenai sejarah, riwayat penemuan, dan upaya pelestarian Candi sambisari. Setelah berkeliling kompleks Candi Sambisari, para pelajar diajak outbond ringan dengan berbagai macam permainan. Acara ini bertujuan untuk membangun teamwork serta saling mengenal di antara mereka. Misalnya memainkan game pindah bola dengan peserta dalam satu group. Peserta outbond harus memasukkan bola ke dalam ember dengan memindahkan dari satu orang ke orang lain dengan piring plastik yang ditaruh di atas kepala. Bagi regu yang menang, masing-masing anggotanya diberi hadiah berupa gantungan kunci berbentuk Candi Prambanan.

Selain melakukan kunjungan ke candi, peserta outbond juga diajak belajar cagar budaya melalui berbagai macam media di kantor BPCB DIY, menonton film cagar budaya, mengamati benda-benda cagar budaya di ruang koleksi arca batu dan ruang koleksi arca perunggu, bermain game cagar budaya, misalnya menyusun puzzle cagar budaya digital maupun manual, dan ular tangga cagar budaya. Sedangkan siswa SMP Negeri 2 Pleret bantul, siswa-siswi diajak melakukan praktek ekskavasi arkeologis di Candi Kedulan, Tirtomartani, kalasan, Sleman. ${ }^{24}$

Metode pembelajaran yang berupa belajar sambil bermain, menurut Penulis sangat bagus jika diangkat sebagai muatan lokal, sebagai salah satu mata pelajaran dalam kurikulum pendidikan dasar dan menengah. Selain itu harapan Sekolah Cagar Budaya sebagai sarana edukasi yang berbasis partisipasi masyarakat dan berkelanjutan dapat berlangsung secara terus menerus. Partisipasi di sini dapat diartikan sebagai keikutsertaan, keterlibatan, dan kebersamaan anggota masyarakat secara aktif, sukarela, dan bertanggung jawab dalam suatu kegiatan untuk memberikan sumbangan, pikiran, tenaga, dana, agar tercapai keberhasilan tujuan dan sasaran pembangunan. ${ }^{25}$ Keberlanjutan diartikan sebagai upaya pelestarian cagar budaya yang dilakukan secara terus menerus dengan memperhatikan keseimbangan aspek ekologis.

Arti penting partisipasi adalah sebagai berikut: ${ }^{26}$

a. Sebagai masukan kebijakan: partisipasi dilakukan berdasarkan pertimbangan bahwa masyarakat yang mungkin akan terkena dampak negatif suatu kegiatan pembangunan mempunyai hak untuk dimintai pendapatnya. Aspirasi dari publik berguna sebagai input dalam pengambilan keputusan;

b. Sebagai strategi: pendapat atau aspirasi masyarakat merupakan sebuah cara untuk mendapatkan dukungan warga terhadap suatu kegiatan, sehingga dampak negatif yang merugikan semua pihak dapat dihindari;

c. Sebagai komunikasi: tidak adanya komunikasi antara warga masyarakat dengan penanggung jawab usaha atau kegiatan akan menimbulkan ketegangan di antara kedua belah pihak;

d. Sebagai media pemecahan publik: partisipasi sebagai cara untuk mengurangi ketegangan dan memecahkan konflik;

e. Sebagai terapi sosial: dengan partisipasi, masyarakat menjadi tidak asing terhadap seluruh kegiatan pembangunan.

23 IE. Hadiyanta, "Refleksi Penegakan Hukum Cagar Budaya di Yogyakarta", http://purbakalayogya.com/artikel-detail-274-Refleksi\%20 Penegakan\%20Hukum\%20Cagar \%20Budaya\%20Di\%20Yogyakarta.html, diakses 18 September 2017.

24 Anonim, "Sekolah Cagar Budaya, Ini Patut Dicontoh, https://www.ngopibareng.id/timeline/sekolah-cagar-budaya-ini-patut-dicontoh-382530, diakses 17 September 2017.

25 Dwita Hadi Rahmi dan Titi Handayani,2009, Pedoman Pelestarian Pasca Bencana Kawasan Pusaka Kotagede Yogyakarta, Indonesia, Jogja Heritage Society, Yogyakarta, hlm. 22. 
Masyarakat diharapkan dapat mengambil peran dalam pelaksanaan peraturan tentang cagar budaya, sehingga perlu dilakukan sosialisasi atau pemberian pemahaman terkait peraturan-peraturan tersebut, supaya masyarakat memahami hak dan kewajibannya terhadap cagar budaya. Sosialisasi peraturan dimaksudkan juga untuk memperoleh masukan masyarakat terhadap penyempurnaan peraturan-peraturan yang ada tersebut. Hal ini telah diakomodasi dalam kegiatan Sekolah Cagar Budaya, dengan kata lain kegiatan Sekolah Cagar Budaya sangat sesuai dengan ketentuan peran serta masyarakat sebagaimana diatur dalam PP No. 10 tahun 1993 tentang Pelaksanaan UU No. 5 Tahun 1992 tentang Benda Cagar Budaya, dan telah sesuai juga dengan UUCB.

Sekolah Cagar Budaya berbasis partisipasi masyarakat dan berkelanjutan mengandung arti bahwa partisipasi masyarakat harus diakomodasi dan diintegrasikan sebagai basis dalam kegiatan Sekolah Cagar Budaya melalui pelestarian cagar budaya yang dilakukan secara terus menerus dengan mengingat kepentingan generasi saat ini dan generasi yang akan datang. Partisipasi masyarakat dalam pelestarian cagar budaya sangat memberikan andil atau peranan dalam keberlanjutan lingkungannya. Dengan sikap sadar untuk melestarikan cagar budaya, masyarakat juga sadar untuk melestarikan fungsi lingkungan hidupnya.

Lingkungan hidup yang baik dan sehat tentu akan menjadikan kualitas hidup masyarakat juga meningkat. Melalui proses internalisasi cagar budaya, berarti menumbuhkan suatu budaya baru dalam diri masyarakat untuk memahami bagaimana mereka memperlakukan cagar budaya dan lingkungan hidupnya yang mendukung keberadaan cagar budaya tersebut, sehingga apa yang dinikmati generasi sekarang juga akan dapat dinikmati oleh generasi yang akan datang. Masyarakat terutama generasi muda akan memahami dan menghargai perkembangan kebudayaan di Indonesia beserta peninggalan-peninggalannya yang penting untuk dilestarikan sampai kapan pun, sehingga kebudayaan masyarakat yang hidup pada masa lampau dapat membuat generasi masa kini bangga terhadap karya bangsanya yang tidak kalah dengan bangsa lain.

Pelaksanaan kegiatan Sekolah Cagar Budaya memerlukan sumber daya manusia yang berkompeten atau mempunyai kemampuan di bidang pelestarian cagar budaya, nilai-nilai sejarah, hukum, dan kebudayaan. Pelaksanaan Sekolah Cagar Budaya menggunakan pendekatan multidisipliner karena permasalahan cagar budaya bersifat komprehensif. Cagar budaya menjadi penting untuk dipertahankan keberadaannya sebagai warisan budaya masa lalu, sebagai sarana bagi para generasi muda untuk belajar peradaban bangsa Indonesia.

Sekolah Cagar Budaya masih menekankan pemahaman pada cagar budaya yang bersifat benda. Sebagaimana diketahui, bahwa yang dimaksudkan sebagai cagar budaya itu terdiri atas 2 macam, yaitu:

a. Cagar budaya bendawi, yang terdiri atas benda cagar budaya, bangunan cagar budaya, struktur cagar budaya, situs cagar budaya, dan kawasan cagar budaya;

b. Cagar budaya non bendawi, yaitu berbagai praktek, representasi, ekspresi, pengetahuan, keterampilan, instrumen-instrumen, obyek, artefak, dan lingkungan budaya yang terkait (yang meliputi berbagai komunitas, kelompok, perseorangan) yang diakui sebagai warisan budaya.

Pelaksanaan kegiatan Sekolah Cagar Budaya dengan mengajak peserta mengunjungi situssitus cagar budaya, berarti peserta hanya paham mengenai cagar budaya bendawi. Seharusnya peserta juga dikenalkan atau ditunjukkan mengenai cagar budaya non bendawi misalnya tari-tarian, lagu daerah, masakan tradisional yang memiliki

26 Hyronimus Rhiti, 2005, Kompleksitas Permasalahan Lingkungan Hidup, Cetakan ke-1, Edisi ke-1, Universitas Atma Jaya Yogyakarta, hlm. 99-100. 
makna tertentu, pakaian adat, upacara adat, alat musik daerah, dan sebagianya. Dengan demikian pengetahuan komprehensif tentang cagar budaya dapat dikuasai oleh peserta Sekolah Cagar Budaya.

Apabila masyarakat paham akan hal ini, maka masyarakat dapat berperan untuk mempertahankan dan melestarikan keberadaan cagar budaya non bendawi yang mereka miliki. Apalagi tidak sedikit generasi muda yang menganggap bahwa sesuatu yang bersifat tradisional itu adalah lawan dari modernisasi, sehingga apa-apa yang tradisional harus ditinggalkan. Pandangan semacam ini tentu saja harus diubah, dengan cara memberikan edukasi akan pentingnya memelihara cagar budaya non bendawi yang jumlahnya di Indonesia lebih banyak dan beragam jika dibandingkan dengan cagar budaya bendawi, melalui kegiatan Sekolah Cagar Budaya yang berbasis partisipasi dan berkelanjutan.

\section{Kesimpulan}

Berdasarkan hasil penelitian dan pembahasan yang telah diuraikan pada bab-bab sebelumnya, maka dapat ditarik kesimpulan sebagai berikut: Pertama, Sekolah Cagar Budaya merupakan program baru yang diluncurkan pada tahun 2017. Kegiatan ini dimaksudkan sebagai upaya sosialisasi bagi masyarakata terutama generasi muda (pelajar) yang dikemas dalam bentuk pembelajaran cagar budaya di sekolah atau di kantor BPCB DIY dan di situs atau lokasi yang mengandung cagar budaya.
Kegiatan Sekolah Cagar Budaya mendapatkan sambutan yang baik dari sekolah-sekolah yang mengikutinya. Kegiatan dilaksanakan kurang lebih 5 jam dengan materi cagar budaya dan aspekaspek yang melingkupinya, peraturan perundangundangan cagar budaya, serta praktek di lapangan atau situs yang meliputi latihan ekskavasi, identifikasi, preservasi, publikasi, pemanduan, dan fotografi cagar budaya. Dalam pelaksanaan Sekolah Cagar Budaya telah dikeluarkan surat Keputusan Kepala Balai Pelestarian Cagar Budaya No. 665/E.18/IQ/2017 tentang Penetapan Standar Pelayanan Sekolah Cagar Budaya Di Balai Pelestarian Cagar Budaya Daerah Istimewa Yogyakarta.

Kedua, Pengaturan Sekolah Cagar Budaya berbasis partisipasi masyarakat dan berkelanjutan adalah menjadikan Sekolah Cagar Budaya sebagai muatan lokal dalam kurikulum sekolah dasar dan menengah. Oleh karena Sekolah Cagar Budaya juga diperuntukkan bagi masyarakat umum, maka untuk masyarakat umum program ini tetap dijalankan sebagaimana saat ini. Agar dapat dilaksanakan secara berkelanjutan dan supaya tujuan Sekolah Cagar Budaya untuk menanamkan kepedulian terhadap cagar budaya tercapai, maka diusulkan bahwa kegiatan ini dituangkan dalam bentuk Peraturan Gubernur tentang Muatan Lokal Cagar Budaya dan Peraturan Gubernur tentang Sekolah Cagar Budaya.

\section{DAFTAR PUSTAKA}

\section{A. Buku}

Hadi Rahmi, Dwita, dan Titi Handayani, 2009, Pedoman Pelestarian Pasca Bencana Kawasan Pusaka Kotagede Yogyakarta, Indonesia, Jogja Heritage Society, Yogyakarta.

Sudikno Mertokusumo, 2010, Bunga Rampai Ilmu Hukum, Cetakan ke 2, Liberty, Yogyakarta.

Rhiti, Hyronimus, 2005, Kompleksitas Permasalahan Lingkungan Hidup, Cetakan ke-1, Edisi ke-1, Universitas Atma Jaya
Yogyakarta.

Rohadi, Tasdiyanto, 2011, Budaya Lingkungan: Akar Masalah dan Solusi Krisis Lingkungan, Cetakan ke 2, Ecologia Press, Yogyakarta. Rosidi, Ajip, 2011, Kearifan Lokal Dalam Perspektif Budaya Sunda, Cetakan 1, PT Kiblat Buku Utama, Bandung.

Tumanggor, Rusmin, Kholis Ridho, Nurochim, 2015, Ilmu Sosial dan Budaya Dasar, Edisi ke 3, Cetakan ke 4, Prenadamedia Group, 
Jakarta.

\section{B. Artikel Dalam Antologi}

Koesnadi Hardjasoemantri, "Kajian Hukum dan Peraturan Perundang-undangan Dalam Pelestarian Warisan Budaya Candi Prambanan", dalam Himawan Pambudi, 2006, Ekologi, Manusia, dan Kebudayaan (Kumpulan Tulisan Terpilih Prof. Dr. Koesnadi Hardjasoemantri, S.H., M.L.), Lapera Pustaka Utama, Yogyakarta.

Tuni Cakabawa, Putu, "Potensi Kearifan Lokal Dalam Pembangunan Berwawasan Lingkungan", dalam Laode M. Syarif dan Andri G. Wibisana, tanpa tahun, Hukum Lingkungan: Teori, Legislasi, dan Studi Kasus, USAID, Kemitraan Partnership, The Asia Foundation.

\section{Artikel Jurnal}

Romana Harjiyatni, Francisca, dan Sunarya Raharja, "Perlindungan Hukum Benda Cagar Budaya Terhadap Ancaman Kerusakan Di Yogyakarta", Mimbar Hukum, Vol. 24, No. 2, Juni 2012.

\section{Peraturan Perundang-undangan}

Undang-Undang Nomor 5 Tahun 1992 tentang Benda Cagar Budaya (Lembaran Negara Republik Inodnesia Tahun 1992 Nomor 27, Tambahan Lembaran Negara Nomor 3470).

Undang-Undang Nomor 32 Tahun 2009 tentang Perlindungan dan Pengelolaan Lingkungan Hidup (Lembaran Negara Republik Inodnesia Tahun 2009 Nomor 140, Tambahan Lembaran Negara Nomor 5059).

Undang-Undang Nomor 11 Tahun 2010 tentang Cagar Budaya (Lembaran Negara Republik Inodnesia Tahun 2010 Nomor 130, Tambahan
Lembaran Negara Nomor 5168).

Peraturan Pemerintah Nomor 10 Tahun 1993 tentang Pelaksanaan Undang-undang No. 5 Tahun 1992 tentang Benda Cagar Budaya (Lembaran Negara Republik Inodnesia Tahun 1993 Nomor 14, Tambahan Lembaran Negara Nomor 3516).

\section{Artikel Internet}

Anonim, "Sekolah Cagar Budaya, Ini Patut Dicontoh, https://www.ngopibareng.id/ timeline/sekolah-cagar-budaya-ini-patutdicontoh-382530, diakses 17 September 2017.

Direktorat Pelestarian Cagar Budaya dan Museum, "Paradigma Pelestarian Cagar Budaya dan Permuseuman", http://kebudayaan. kemdikbud.go.id/ditpcbm/2015/05/11/ paradigma-cagar-budaya-danpermuseuman/, diakses 7 Mei 2017.

Faizi, Cholis, "Ada Lagi Nih! Sekolah Cagar Budaya Agar Generasi Muda Mencintai Candi”, http;//nasional.indopos.co.id/ read/2017/03/21/91982/Ada-Lagi-nihSekolah-Cagar-Budaya-Agar-GenerasiMuda-Mencintai-Candi, diakses 2 April 2017.

Hadiyanta, IE, "Reflesksi Penegakan Hukum Cagar Budaya di Yogyakarta", http:// purbakalayogya.com/artikel-detail-274 Refleksi\%20Penegakan\%20Hukum\%20 Cagar \%20Budaya\%20Di\%20Yogyakarta. html, diakses 18 September 2017.

Yuliana, Tri, "Internalisasi Nilai-nilai Budaya Dalam Pembentukan Kepribadian dan Karakter (Antropologi SMA Kelas X: Bab 3)", blog.unnes.ac.id , diakses tanggal 20 September 2017. 